\title{
Characterization of Sm14 Related Components in Different Helminths by Sodium Dodecyl Sulphate-Polyacrylamide Gel Electrophoresis and Western Blotting Analysis
}

\author{
Nilton Thaumaturgo, Mônica Magno Vilar, Ricardo Edelenyi, Miriam Tendler ${ }^{+}$
}

Laboratório de Esquistossomose Experimental, Departamento de Helmintologia, Instituto Oswaldo Cruz-Fiocruz, Av. Brasil 4365, 21045-900 Rio de Janeiro, RJ, Brasil

Sm14 was the first fatty acid-binding protein homologue identified in helminths. Thereafter, members of the same family were identified in several helminth species, with high aminoacid sequence homology between them. In addition, immune crossprotection was also reported against Fasciola hepatica infection, in animals previously immunized with the Schistosoma mansoni vaccine candidate, $r$-Sm14. In the present study, data on preliminary sodium dodecyl sulphate-polyacrylamide gel electrophoresis and Western blotting analysis of nine different helminth extracts focusing the identification of Sm14 related proteins, is reported. Out of these, three extracts - Ascaris suum (males and females), Echinostoma paraensei, and Taenia saginata - presented components that comigrated with Sm14 in SDS-PAGE, and that were recognized by anti-rSm14 policlonal serum, in Western blotting tests.

Key words: Sm14 - Schistosoma mansoni - immune crossreaction - fatty acid-binding protein

Crossreaction among helminths has been extensively described for decades (Hillyer et al. 1988), although the true biological role of such crossreaction remained to be more clearly elucidated.

Heterologous resistance between Schistosoma mansoni and Fasciola hepatica has been reported by Hillyer and coworkers (Hillyer 1987, Christensen et al. 1987, Hillyer et al. 1988, Hillyer 1995). In previous studies it has been described that the recombinant molecule, $r$ Sm14, derived from $S$. mansoni adult worm extract, induces immune crossprotection against infection by $F$. hepatica in Swiss outbred mice (Tendler et al. 1996). RodriguezPerez et al. (1992) demonstrated a high aminoacid sequence homology between Sm14 and the F. hepatica fatty acidbinding protein (FABP), called Fh15, possibly responsible for the reported crossprotection.

Sm14 was the first FABP homologue identified in helminths (Moser et al. 1991). Thereafter, members of the same family were identified in several helminth species, with high aminoacid sequence homology between them: S. japonicum-Sj-FABP (Becker et al. 1994); Dictyocaulus viviparus (Britton et al. 1995); Monienzia expansaMonienzia LBP (Janssen \& Barret 1995); Toxocara canisTcSL-2 (Gems et al. 1995); Dirofilaria immitis (Poole et al. 1996); Echinococcus granulosus- EgDf1 (Esteves et al. 1997); F. gigantica-Fg-FABP (Smooker et al. 1997); Ascaris suum-As-p18 (Mei et al. 1997); and Brugia malayi

This work was supported by Fiocruz and CNPq.

${ }^{+}$Corresponding author Fax: +55-21-2260.4866. E-mail: mtendler@ioc.fiocruz.br

Received 18 June 2002

Accepted 15 August 2002
(Michalski \& Weil 1999).

The FABPs may be particularly important to schistosomes in the uptake, transport and compartimentalization of host derived fatty acids, since these parasites lack the oxygen dependent pathways required for the synthesis of sterols and fatty acids (Esteves et al. 1997).

Specifically, in the case of A. suum, that was included in this study, the FABP homologue component, As-p18, presented similar levels of aminoacid sequence homology, for Sm14 and Fh15 (respectively 28\% and 30\%) (Mei et al. 1997). Esteves et al. (1997), presented a philogenetics analysis of helminth FABPs, in which it was demonstrated that Sm14 and Fh15 are closely related to Sj-FABP and EgDf1.

Present data refer to preliminary SDS-PAGE and Western blooting analysis of nine different helminth extracts focusing the identification of Sm14 related proteins.

Extracts were prepared basically as described previously for S. mansoni (Tendler \& Scapin 1979, Tendler et al. 1982, Thaumaturgo et al. 2001). Additional members of the three major helminth taxonomic groups, such as Echinostoma paraensei (Trematode), Hymenolepis diminuta, Dipylidium caninum and Taenia saginata (Cestodes) and Aspiculuris tetraptera, Toxocara sp., A. suum (males and females) and Toxocara canis (Nematodes) were subjected to SDS-PAGE and Western blotting analysis (Towbin et al. 1979).

In three out of nine helminth species $-A$. suum (males and females); E. paraensei; and T. saginata - it was detected parasite proteins that clearly comigrated with $r$ Sm14 in SDS-PAGE. In addition, these proteins were recognized by anti-rSm14 policlonal serum, in Western blotting (Figs 1,2).

Herein presented results indicate the occurrence of immune crossreaction mediated by Sm14 and components 

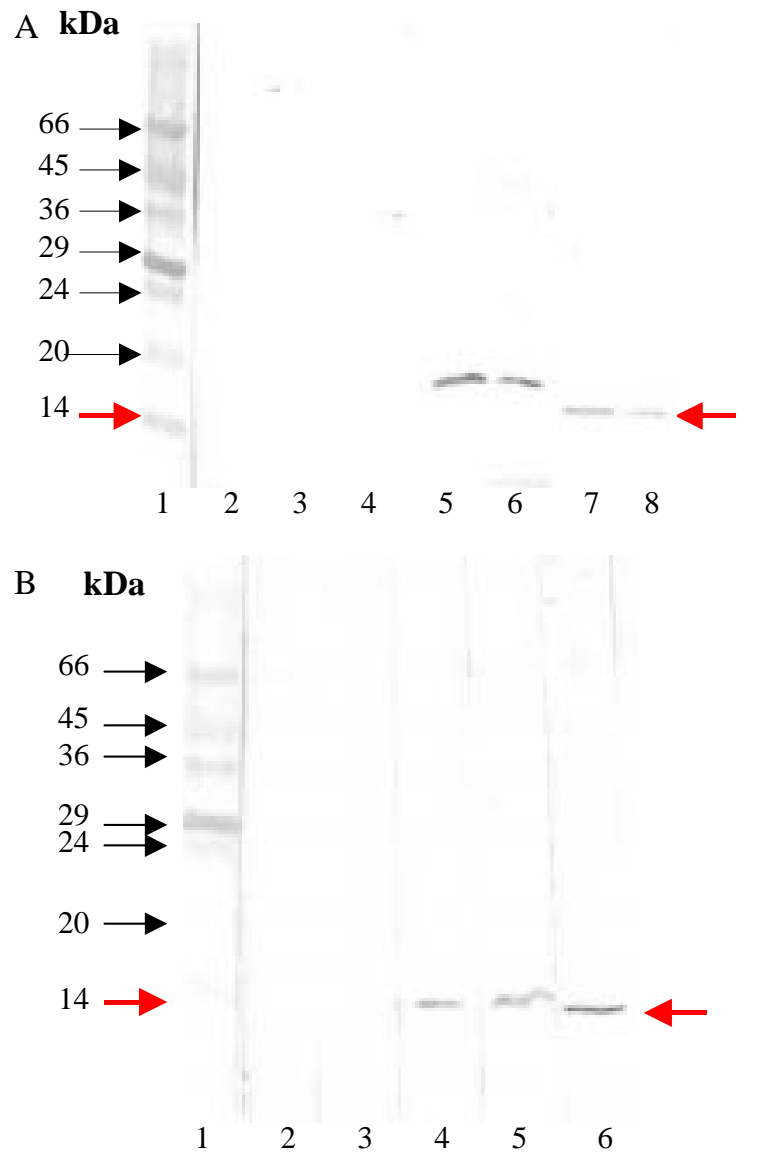

Western blotting analysis of different helminth extracts against rabbit anti-rSm14 serum. A-lanes 1: low molecular weight marker, Dalton Mark VII-L Sigma; 2: Hymenolepis diminuta (protein concentration $-0.128 \mathrm{mg} / \mathrm{ml})$; 3 : Aspiculuris tetraptera $(0.429 \mathrm{mg} /$ $\mathrm{ml})$; 4: Toxocara $\mathrm{sp}$. (1.340 mg/ml); 5: Ascaris suum (males) $(1.430$ $\mathrm{mg} / \mathrm{ml}) ; 6$ : A. suum (females) $(2.060 \mathrm{mg} / \mathrm{ml}) ; 7:$ Schistosoma mansoni (males) $(1.431 \mathrm{mg} / \mathrm{ml}) ; 8:$ S. mansoni (females) $(1.788$ $\mathrm{mg} / \mathrm{ml}$ ); B-lanes 1: low molecular weight marker, Dalton Mark VIIL Sigma.; 2: Dipylidium caninum $(0.964 \mathrm{mg} / \mathrm{ml}) ; 3:$ T. canis $(0.912$ $\mathrm{mg} / \mathrm{ml})$; 4: Echinostoma paraensei $(1.106 \mathrm{mg} / \mathrm{ml})$; 5: Taenia saginata $(1.328 \mathrm{mg} / \mathrm{ml}) ; 6$ : SE $(1.273 \mathrm{mg} / \mathrm{ml})$.

of different helminth species, in which homologous members to FABP family were previously detected. Considering that significant immune crossprotection has been formerly described for the related trematodes, $S$. mansoni and $F$. hepatica in animals previously vaccinated with $\mathrm{r}-\mathrm{Sm} 14$, it is reasonable to further investigate this mechanism in other helminth infections.

\section{REFERENCES}

Becker MM, Kalinna BH, Waine GJ, McManus DP 1994. Gene cloning, overproduction and purification of a functionally active cytoplasmic fatty acid-binding protein (Sj-FABPc) from the human blood fluke Schistosoma japonicum. Gene 148: 321-325.

Britton C, Moore J, Gilleard JS, Kennedy MW 1995. Extensive diversity in repeat unit sequences of the cDNA enconding the polyprotein antigen-allergen from the bovine lungworm Dictyocaulus viviparus. Mol Biochem Parasitol 72: 77-88.

Christensen NO, Nansen P, Fagbemi BO, Monrad J 1987. Het- erologous antagonistic and synergistic interactions between helminths and between helminths and protozoans in concurrent experimental infection of mammalian hosts. Parasitol Res 73: 387-410.

Esteves A, Joseph L, Paulinos M, Ehrlich R 1997. Remarks on the phylogeny and structure of fatty acid binding proteins from parasitic platyhelminths. Int J Parasitol 27: 1013-1023.

Hillyer GV 1987. Heterologous resistance in schistosomiasis. Mem Inst Oswaldo Cruz 82: 171-174.

Hillyer GV 1995. Comparison of purified $12 \mathrm{kDa}$ and recombinant $15 \mathrm{kDa}$ Fasciola hepatica antigens related to a Schistosoma mansoni fatty acid binding protein. Mem Inst Oswaldo Cruz 90: 249-253.

Hillyer GV, García Rosa MI, Alicea H, Hernandez A 1988. Successful vaccinations against murine Schistosoma mansoni infection with a purified $12 \mathrm{KD}$ Fasciola hepatica crossreactive antigen. Am J Trop Med Hyg 38: 103-110.

Gems D, Ferguson CJ, Robertson BD, Nieves R, Page AP, Blaxter ML, Maizels RM 1995. An abundant, trans-spliced mRNA from Toxocara canis infective larvae encodes a 26$\mathrm{kDa}$ protein with homology to phosphatidylethanolaminebinding proteins. J Biol Chem 270: 18517-18522.

Janssen D, Barret J 1995. A novel lipid-binding protein from the cestode Moniezia expansa. Biochem J 311: 49-57.

Mei B, Kennedy MW, Beauchamp J, Komuniecki PR, Komuniecki R 1997. Secretion of a novel, developmentally regulated fatty acid-binding protein into the perivitelline fluid of the parasitic nematode, Ascaris suum. J Biol Chem 272: 9933-9941.

Michalski ML, Weil GJ 1999. Gender-specific gene expression in Brugia malayi. Mol Biochem Parasitol 104: 247-257.

Moser D, Tendler M, Griffiths G, Kinklert MQ 1991. A 14kDa Schistosoma mansoni polypeptide is homologous to a gene family of fatty acid-binding proteins. J Biol Chem 266: 8447-8454.

Poole CB, Hornstra LJ, Benner JS, Fink JR, McReynolds LA 1996. Carboxy-terminal sequence divergence and processing of the polyprotein antigen from Dirofilaria immitis. Mol Biochem Parasitol 82: 51-65.

Rodríguez-Pérez J, Rodríguez-Medina JR, García-Blanco MA, Hillyer GV 1992. Fasciola hepatica: molecular cloning, nucleotide sequence, and expression of a gene enconding a polypeptide homologous to a Schistosoma mansoni fatty acid-binding protein. Exp Parasiotol 74: 400-407.

Smooker PM, Hickford DE, Vaiano AS, Spithill TW 1997. Isolation, cloning, and expression of fatty-acid binding proteins from Fasciola gigantica. Exp Parasitol 85: 86-91.

Tendler M, Scapin M 1979. The presence of Schistosoma mansoni antigens in solutions used for storing adult worms. Rev Inst Med Trop São Paulo 21: 293-296.

Tendler M, Brito CA, Vilar MM, Serra-Freire N, Diogo CM, Almeida MS, Delbem ACB, Silva JF, Savino W, Garratt RC, Katz N, Simpson AJG 1996. A Schistosoma mansoni fatty acid-binding protein, Sm14, is the potential basis of a dual-purpose anti-helminth vaccine. Proc Natl Acad Sci USA 93: 269-273.

Tendler M, Lima AO, Magalhães Pinto R, Cruz M, Brascher H, Katz N 1982. Immunogenic and protective activity of na extract of Schistosoma mansoni. Mem Inst Oswaldo Cruz. 77: 275-283.

Thaumaturgo N, Vilar MM, Diogo CM, Edelenyi R, Tendler M 2001. Preliminary analysis of Sm14 in distinct fractions of Schistosoma mansoni adult worm extract. Mem Inst Oswaldo Cruz 96: 79-83.

Towbin H, Satquet T, Gordon J 1979. Electrophoretic transfer of proteins from polyacrylamide gels to nitrocellulose sheets: procedure and some applications. Proc Natl Acad Sci USA 76: 4350-5354. 